\title{
ACONTECIMENTOS DISCURSIVOS DOS CORPOS NEGROS ASFIXIADO E ESCULPIDO: IRRUPÇ̃̃O DE SABERES DOMINADOS NAS MÍDIAS
}

\author{
DISCURSIVE EVENTS OF THE CHOKING AND \\ CARVED BLACK BODIES: IRRUPTION OF DOMINATED \\ KNOWLEDGE IN THE MEDIA
}

\author{
Claudemir Sousa ${ }^{1}$ \\ [https://orcid.org/0000-0002-5318-5040] \\ DOI: 10.30612/raido.v15i37.13642
}

\begin{abstract}
RESUMO: Neste artigo, analisamos a discursivizaçáo do acontecimento do corpo negro asfixiado de George Floyd na mídia voltada ao público negro e sua relaçăo com os protestos intitulados "Black lives matter", que incluiu a elaboraçâo da estátua da militante britânica Jen Reid. O objetivo é analisar quais acontecimentos estăo à volta desses enunciados produzidos nas mídias alternativas acerca desse evento. Para tanto, construímos um corpus composto por quatro matérias de dois portais, que săo: o site Mundo Negro e o Portal Geledés. O aporte teórico-metodológico mobilizado se baseia nos princípios da análise enunciativa, que orienta os Estudos Discursivos Foucaultianos. Concluímos que a discursivizaçăo da morte de Floyd constituiu um objeto da mídia alternativa pela recorrência aos dizeres da mídia corporativa, em um processo em que ocorre a formaçăo de conceitos que constroem temas, organizam as formas estratégicas de apresentaçăo dos enunciados e delimitam os modos de os sujeitos negros se posicionaram sobre esse acontecimento nesses portais.
\end{abstract}

Palavras-chave: Discurso; Mídia; Corpo; Negritude; Black Lives Matter.

ABSTRACT: In this article, we analyze the discursivization of the event of George Floyd's asphyxiated black body in the media aimed at black audiences and its relationship with the protests entitled "Black lives matter", which included the elaboration of the statue of the British militant Jen Reid. The aim is to analyze what events are around these statements produced in alternative media about this case. For this purpose, we used as corpus four statements from two portals, which are: the websites "Mundo Negro" and "Geledés". The theoretical-methodological contribution mobilized is based on the principles of enunciative analysis, which guides the Foucaultians Discursive Studies. We concluded that the discursivization of Floyd's death constituted an object of the alternative media with recurrence to the sayings of the corporate media, and

1 Instituto Federal de Educaçâo, Ciência e Tecnologia do Maranhâo (IFMA), campus Pedreiras. Doutor em Linguística e Língua Portuguesa. Professor substituto do IFMA. E-mail: claudemir201089@ hotmail.com. 
in this process there is the formation of concepts that build themes, organize the strategic forms of presentation of statements and delimit the ways of black people positioned themselves on this case on those websites.

Keywords: Discourse; Media; Body. Blackish; Black Lives Matter.

\section{INTRODUÇÃO}

No dia 25 de maio de 2020, Derek Chauvin assassinou George Floyd após asfixiá-lo com o seu joelho. 0 primeiro estava armado, o segundo, desarmado. $O$ primeiro era um policial com um contingente de 3 policiais para apoiá-lo, enquanto o segundo, um cidadăo comum que estava sozinho. 0 primeiro é um homem branco, o segundo, um homem negro. Ambos, estadunidenses.

Durante os 8:46 minutos, havia um policial que os observava calado. Floyd agonizando sob o joelho de Chauvin. Calado porque era o seu trabalho. Calado porque năo tinha nada a ver com ele. Calado porque era mais um dado para a estatística (TAKAHASHI, 2020, online).

A escultura de Jen Reid, manifestante negra do movimento Black Lives Matter, substitui a partir desta quarta-feira (15) a estátua do traficante de escravos britânico Edward Colston (PRADO, 2020a, online).

Quais regularidades podemos encontrar entre o corpo negro de George Floyd asfixiado e o de Jen Reid esculpido em resina preta? Que história cruza essas vidas paralelas, "que só sobrevivem do choque com um poder que năo quis senăo aniquilá-las, ou pelo menos apagá-las" (FOUCAULT, 2003, p. 210)? As respostas năo estâo só nesses dois excertos, que expressam apenas um episódio da longa história de violência contra o corpo negro e das lutas desses sujeitos contra o racismo.

Para situar essa discussăo, vamos nos ater, inicialmente, ao primeiro enunciado, um excerto de uma reportagem do estudante Henrique Yagui Takahashi, publicada originalmente no Le Monde Diplomatique Brasil e ampliada para o portal Geledés, que nos dá uma dimensâo de como o assassinato do cidadāo negro americano George Floyd foi discursivizado na mídia. A "pesada e temível materialidade" (FOUCAULT, 2007, p. 9) desse enunciado apresenta uma fotografia de Derek Chauvin com o joelho esquerdo sobre o pescoço de Floyd enquanto Tou Thao fica em posiçăo estática para garantir a segurança do policial de poder matar. Essa cena foi registrada em vídeo e fotografia, replicados milhóes de vezes em diferentes países.

A materialidade linguístico-discursiva e histórica desse enunciado expóe a existência de lutas em torno da questăo "quem somos nós?" (FOUCAULT, 2009), que săo transversais, porque năo se limitam ao local onde ocorreram; contrárias aos efeitos do poder enquanto tais, porque recriminam o poder policial sobre a vida e a morte dos corpos negros; imediatas, porque criticam as instâncias de poder mais próximas; questionadoras do estatuto do indivíduo, porque clamam pelo direito à diferença e questionam a imposiçăo de uma identidade; e sâo contrárias aos privilégios do saber e aos efeitos do poder a ele ligados.

A imagem do corpo negro asfixiado de George Floyd é histórica e aponta para o lugar da proveniência (FOUCAULT, 2013a) de um sujeito que cometeu um erro e foi 
condenado por alguém năo tinha o direito de matá-lo. Seu julgamento foi realizado prévia e simbolicamente, em virtude dos estigmas que o acompanham. A sua morte é a sançấo final do erro e traz consigo a sua ligaçăo com um grupo étnico-racial. A atitude do policial é a vingança de um grupo que se julga superior, porque goza de privilégios nas relaçóes de poder, e uma história que se repete todos os dias nos Estados Unidos da América (EUA) e em outros países. Uma luta transversal.

É Foucault (2013a) quem encara o corpo como o lugar da proveniência, ou seja, do pertencimento a um grupo e da dispersáo de acontecimentos. No corpo negro de Floyd se localizam os estigmas dos acontecimentos passados e dele nascem os erros, os desfalecimentos. Esse corpo é atravessado de história e arruinado por ela. É a linguagem que marca os acontecimentos e promove a sua dispersăo na história e é nessa dispersăo que se pode encontrar a proveniência do corpo.

O corpo asfixiado de George Floyd, que grita "I can't breath" (năo consigo respirar) enquanto é sufocado até a morte, durante $8 \mathrm{~min}$. 46 seg., é atravessada pela história de mais de três séculos de escravidăo e de constantes suplícios do corpo negro.

A condiçăo de emergência desse enunciado foi o contexto de uma pandemia, iniciada na China, em dezembro de 2019, e espalhada ao longo de 2020 para diferentes continentes e países, obrigando à adoçấo do isolamento social como forma de conter a expansâo do corona vírus. É na esteira dessa expansâo mundial do vírus que ocorre a difusâo global da imagem do corpo negro de George Floyd asfixiado e morto. É na sequência desse acontecimento que ocorre uma série de protestos em diferentes países contra o racismo, intitulados de "Black lives matter" (vidas negras importam), expressâo que passou a denominar um movimento contra o racismo e a violência policial nos EUA desde 2014 e que, após esse ato, ganhou maior notoriedade.

A luta contra o racismo no mundo năo é, em si mesma, nova. O que a torna nova é o acontecimento à sua volta (FOUCAULT, 2007). O isolamento social, a disponibilidade de tempo e a maior difusăo e recepçâo de informaçăo fez pessoas negras e brancas protestarem em diferentes países contra a violência policial a que os corpos negros estáo expostos, o que mostra a existência de uma necropolítica (MBEMBE, 2016) para essa camada populacional em todo o mundo, ou seja, uma política de fazer morrer, distinta da biopolítica, que funciona pelo fazer viver.

Os protestos contra a morte de Floyd incluem a destruiçáo de símbolos do colonialismo, como a estátua de Colston citada na segunda epígrafe, clamores para que o mundo desfaça o racismo estrutural, tema que passa a ser intensamente falado, de tal forma que atores pediram desculpas por fazerem blackface (pintura do rosto de preto para encenar personagem negro), episódios racistas de séries foram removidos, filmes colocaram advertência antes do início sobre conteúdos racistas, cenas extras foram inseridas para explicar o contexto de produçăo da época, cantores lançaram músicas falando sobre o tema, a indústria da moda refletiu sobre ele, inclusive com publicaçăo de capas de revistas com mulheres negras e gordas, etc.

No Brasil, esse tema foi pautado nas mídias televisivas, impressas e digitais. A Rede Globo de Televisâo, maior da América Latina, apoiou os protestos antirracistas, mas foi duramente criticada por promover um debate racial apenas com jornalistas brancos na Globo News. No dia seguinte, esse mesmo grupo promoveu um debate apenas com jornalistas negros, reapresentado na TV Globo aberta, no programa Globo Repórter. 
Essa discursivizaçăo trouxe também questionamentos sobre uma real mudança social, se é apenas um modismo ou mais uma forma de ganhar dinheiro com a causa racial. De qualquer forma, a emergência das lutas contra o racismo é apenas um episódio na longa duraçăo da história. Mesmo assim, năo se pode deixar de dizer que a difusăo global da imagem do corpo negro americano sendo assassinado ganhou muito mais repercussâo do que outros casos que ocorrem diariamente em diversos países.

Esse acontecimento se inscreve em uma regularidade de eventos históricos trágicos ocorridos nos Estados Unidos, como o ataque às Torres Gêmeas, em 11 de setembro de 2001, que promoveu a entrada em um universo discursivo em que a circulaçăo de palavras e imagens é dominada pelas lógicas da globalizaçăo (COURTINE, 2006), além de ataques a escolas, nos quais vidas americanas foram assassinadas, mas năo em quantidade superior ao ocorrido em outras partes do planeta.

Assim, tendo em vista a grande visibilidade que o acontecimento do corpo negro asfixiado de George Floyd ganhou e a sequência de atos antirracistas, que incluia elaboraçâo da estátua de Jen Reid, neste artigo, analisamos a discursivizaçấo do referido assassinato e sua relaçăo com os protestos intitulados "Black lives matter" na mídia voltada ao público negro. Para tanto, empreendemos uma pesquisa pela expressáo "Black lives matter" em dois portais, que foram: o site Mundo Negro e o Portal Geledés, no dia 27 de agosto de 2020, e apresentamos dois quadros com os resultados que foram retornados. Com base nos princípios da análise enunciativa, de Foucault (2008), promovemos um recorte no arquivo sobre tal tema e selecionamos alguns enunciados para discussáo aqui, como detalharemos na seçấo metodológica deste estudo.

O aporte teórico que mobilizamos para essa discussâo săo os Estudos Discursivos Foucaultianos, baseados na arqueogenealogia do discurso do autor (FOUCAULT, 1999; 2003; 2007; 2008; 2009; 2013a; 2013b). Este artigo está estruturado do seguinte modo: adiante, traremos algumas consideraçôes teóricas acerca do corpo, do acontecimento e do saber nas discussôes arqueogenealógicas de Foucault. Em seguida, descreveremos o processo de montagem do corpus com base na análise enunciativa de Foucault (2008). Depois disso, traremos a discussăo a partir das matérias selecionadas para análise e, por último, as consideraçōes finais.

\section{0 CORPO COMO LUGAR DA EMERGÊNCIA DO ACONTECIMENTO NA HISTÓRIA: GENEALOGIA E SABERES DOMINADOS}

Os conceitos de corpo, acontecimento e saber emergem nas discussōes de Foucault sobre a formaçâo de determinados domínios de saber científico que objetivam o homem; as disciplinas, a regulamentaçăo e a normalizaçăo dos corpos em práticas de biopolítica e governamentalidade, sob açâo de um biopoder (compreendido, em primeira instância, como um poder sobre a vida em seu aspecto biológico); e as formas de subjetivaçăo, nas quais o sujeito realiza uma experiência de si, tendo o corpo como o centro.

A noçấo de acontecimento é da ordem da produçâo de enunciados, nâo se restringindo a um evento histórico passado, e sim abrangendo a sua discursivizaçăo. A análise enunciativa proposta por Foucault (2008) considera o discurso em sua irrupçăo de acontecimentos, ou seja, descreve os momentos em que ele emerge como começos relativos, em sua dispersâo temporal, que lhe possibilita ser transformado, esquecido, em vez de remeter à sua longínqua origem, anterior a qualquer influência. 
Essa análise dos acontecimentos discursivos coloca a questâo "como apareceu um determinado enunciado, e nâo outro em seu lugar?" (FOUCAULT, 2008, p. 30), porque leva em consideraçâo os princípios de raridade, segundo o qual nem tudo pode ser dito; de dispersăo, pois os enunciados năo se encontram agrupados; e de descontinuidade, que implica renuncia à suposta ideia de linearidade da história.

Foucault (2013a) considera que a história năo é uma narrativa sequencial de acontecimentos que se organizam linearmente, e sim o lugar do acontecimento pensado como forma de emergência, que é a irrupçâo sem um agente causador, e também de proveniência, que "diz respeito ao corpo" (FOUCAULT, 2013a, p. 64). A proveniência é pensada como uma origem năo fundante ou essencialista, mas fragmentária, heterogênea.

A genealogia, como pesquisa da proveniência, possibilita reencontrar a proliferaçăo dos acontecimentos, demarcar os acidentes, os ínfimos desvios que deram nascimento ao que nós somos. A genealogia é esse empreendimento que mostra as camadas heterogêneas que tornam instável nossa proveniência.

O corpo é o lugar da proveniência, a "superfície de inscriçâo dos acontecimentos" (FOUCAULT, 2013a, p. 65). A genealogia é o ponto de articulaçăo do corpo com a história, "corpo inteiramente marcado de história e a história arruinando o corpo" (FOUCAULT, 2013a, p. 65). O corpo resulta dos regimes que o constroem, como o trabalho, o repouso, as festas, o envenenamento, a alimentaçâo, os valores, os saberes, as disciplinas e as formas de relaçấo consigo.

Além de estar sujeito a formas de agenciamento de saberes e poderes, o corpo cria formas de resistência. O corpo é o lugar onde nascem nossos desejos e os saberes que nos conduzem a formas de vida livre de sujeiçôes. Foucault (2013b) considera a genealogia como empreendimento para libertar da sujeiçăo os saberes históricos, ou seja, uma forma de reativaçăo dos saberes menores das hierarquias de poderes de discursos que se propóem unitários, científicos e verdadeiros como forma de desqualificar outros saberes.

Dessa discussăo, decorre o seu conceito de saberes dominados, compreendidos como aqueles saberes das pessoas, considerados "ingênuos, hierarquicamente inferiores, saberes abaixo do nível requerido de conhecimento ou de cientificidade" (FOUCAULT, 2013b, p. 266). Para Foucault (2008, p. 204), "um saber é aquilo de que podemos falar em uma prática discursiva". As pesquisas genealógicas se articulam com a arqueologia, pois essa é um método de análise dos saberes dominados, cuja ativaçăo se faz pela genealogia como tática, que os faz emergir no interior de grandes blocos de saber.

As investigaçôes feitas por Foucault situam o contexto europeu, mas, mesmo assim, auxiliam-nos, na medida em que podemos fazer alguns deslocamentos para tratar do corpo negro, que possui uma história de objetivaçăo por saberes, disciplinamento e formas de resistência em países colonizados que faz emergir diferentes práticas. As discussóes de Foucault (1999) sobre a emergência do fazer viver e deixar morrer na Europa no século XVIII, por exemplo, năo têm a mesma cronologia em todos os países.

Até o século XIX, o Brasil viveu diferentes processos disciplinares do corpo negro. Findada a escravizaçấo como um sistema social instituído legalmente, persistiram 
formas de exclusâo e de disciplinamento desse corpo, sob a açăo de um necropoder, que se exerce por meio da necropolítica (MBEMBE, 2016), ou seja, de uma política de exposiçấo à morte ou de fazer morrer os sujeitos tidos como indesejáveis.

Nos séculos XVIII e XIX, os julgamentos feitos pelas classes senhorias de que os negros eram indolentes, facinorosos ou com capacidades produtivas inferiores, com domínio rudimentar de práticas de produçấo, levou à exclusăo do direito agrário e ao confinamento desses corpos em áreas rurais ou suburbanas năo cultiváveis (ALMEIDA, 2008). Na atualidade, essa condenaçâo do sujeito negro feita a priori, por julgá-lo como potencialmente criminoso, tem como efeito sua inserçăo em espaços disciplinares e de exclusáo, como os quilombos, as favelas, os assentamentos, os hospitais psiquiátricos e as prisóes, nos quais săo constantemente assassinados.

Há uma suposta propensăo à criminalidade nos corpos negros que se apoia em discursos e saberes formulados em domínios científicos como a biologia evolucionista e a frenologia (SCHWARCZ, 1993). Tal discurso fomenta a violência policial contra a populaçăo negra, objeto de críticas de variadas ordens e, ao mesmo tempo, elogiada e defendida por sujeitos que se beneficiam dela, por acreditarem que fazem parte da parcela da populaçăo que merece a proteçăo da lei ao passo que a outra parcela, constituída por sujeitos marginalizados, negros, pobres e habitantes de áreas suburbanas, năo merece essa proteçăo. Essa polarizaçăo revela a remanência (FOUCAULT, 2008) de um discurso e de uma prática de colonizaçáo dos corpos negros, que os concebem como merecedores de morrer por terem uma suposta potencialidade criminosa.

Ao mesmo tempo, emergem saberes que contestam esses discursos e práticas. Desde o século XIX, autores da literatura afro-brasileira, a imprensa negra, organizaçóes sociais, como o Movimento Negro e os Centros de Cultura Negra, além de trabalhos acadêmicos de autores como Lélia Gonzales, Abdias do Nascimento, Clovis Moura, etc., formulam saberes que questionam a condenaçâo a priori do corpo negro.

A forma como a polícia age em abordagens a negros é denunciada há algumas décadas por integrantes do Movimento Negro e pesquisadores universitários que a atribuem ao racismo estrutural decorrente do passado colonial e escravocrata. Entretanto, os assassinatos diários de moradores de favelas, comunidades quilombolas e indígenas por policiais ou grileiros entraram na ordem do normal no Brasil, que pratica uma necropolítica (MBEMBE, 2016) para esses corpos, que os mata ou deixa morrer.

Normal que também foi abalado na ordem discursiva brasileira, quando eclodiram os protestos contra a morte de George Floyd. Houve, no Brasil, manifestaçóes contra o assassinato de Joăo Pedro, de 14 anos, atingido por um tiro disparado por um policial que fazia operaçóes em uma favela no Rio de Janeiro (RJ), e a morte de Miguel, criança negra e Recife, Pernambuco (PE), após cair no văo de um elevador do prédio onde sua măe, mulher negra e empregada doméstica, trabalhava para uma família branca, fenômeno que também é uma herança escravista e se integrou ao normal de nossa sociedade. Esse fato criou revolta porque o botáo do elevador foi apertado pela mulher branca empregadora da mâe da criança que morreu.

Nesse sentido, na seçâo que segue vamos descrever de que maneira e por quais critérios selecionamos e organizamos o corpus dessa discussăo sobre a discursivizaçăo da morte de George Floyd e dos protestos intitulados "Black lives matter" na mídia. 


\section{UM PERCURSO METODOLÓGICO PARA ANÁLISE ENUNCIATIVA DO CORPO NEGRO NA MÍDIA}

Para compor o corpus deste estudo, utilizamos como critério que a superfície de emergência (FOUCAULT, 2008) fosse uma mídia voltada para o público negro. Escolhemos dois sites: o Portal Geledés e o site Mundo Negro. Ambos integram o grupo das mídias alternativas, porém se inter-relacionam com as mídias corporativas. A grande mídia tem sido o objeto privilegiado de estudo, o que nos coloca diante de uma visāo oficial da história, tida como verdadeira e unitária.

Capelato (2014) considera que os jornais da grande imprensa săo uma importante fonte e objeto de estudos da história do tempo presente. Os representantes dos jornais da grande imprensa brasileira atuarem como apoiadores ou opositores dos governos e participarem de movimentos que mudaram os rumos da história nacional. Para Weffort (1984), os jornais promovem articulaçóes, conspiraçóes e criam fatos e realidades que interferem nos rumos da história, pois sáo empresas familiares que buscam na política formas de se legitimar e sobreviver.

Năo se pode considerar que as mídias alternativas sejam isentas, visto que, atualmente, ocorre um processo de convergência das mídias (JENKINS, 2009), caracterizado pela colisăo entre as novas e as velhas mídias, pelo cruzamento entre as mídias corporativas e as mídias alternativas e pela interaçấo entre o poder do produtor de mídia e do consumidor. Mesmo assim, sâo as grandes corporaçōes que fornecem as bases para a produçáo de informaçóes e de conteúdos que circulam em escala global. Nesse sentido, os dois portais têm como tema ou objeto o universo afro-descendente e veiculam conteúdos para o público negro, conforme consta nas suas descriçóes. 0 "Geledés - Instituto da Mulher Negra" foi criado pela filósofa Sueli Carneiro, em 1988, em Sảo Paulo, e o site, em 1997, também por ela. Já o "Mundo Negro" foi criado pela jornalista Silvia Nascimento.

Outro critério que definimos foi que buscaríamos nos sites pela expressâo "Black lives matter", selecionando apenas as matérias relativas ao ano de 2020 e relacionadas ao assassinato de George Floyd. Adotamos esses critérios porque sabemos das possibilidades e limites de trabalhar com um arquivo aberto no meio digital. Existe um arquivo muito maior de reportagens sobre tal expressâo em ambos os portais. Foucault (2008, p. 147) compreende o arquivo como "a lei do que pode ser dito, o sistema que rege o aparecimento dos enunciados como acontecimentos singulares" e também o que faz com que as coisas ditas năo se acumulem indefinidamente nem se agrupem em uma linearidade, mas segundo regularidades próprias que o analista deve fazer emergir.

O arquivo é o que possibilita enunciar. Ele é inapreensível em sua totalidade. É no seu interior que falamos e, portanto, ele é aberto. Muitas outras formulaçōes sobre esse acontecimento serāo feitas, mesmo assim, em uma concepçâo de história como acontecimento isso năo representa um obstáculo.

Assim, ao pesquisar pela expressâo "Black lives matter" no site Mundo Negro, foram retornados nove (9) resultados do ano de 2020, que foram os seguintes: 


\section{Tabela 1 - Resultados para "Black lives matter" no site Mundo Negro}

\begin{tabular}{|c|c|}
\hline Data & Título \\
\hline 02/06/2020 & BlackOutTuesday: Artistas aderem a campanha em apoio ao movimento negro \\
\hline 04/06/2020 & $\begin{array}{l}\text { \#blacklivesmatter: Após mobilizações nas redes sociais procura por influenciadores negros } \\
\text { aumenta. }\end{array}$ \\
\hline 26/06/2020 & Fotógrafos contam suas experiências nas manifestações ‘Black Lives Matter’ em Nova York \\
\hline 16/07/2020 & Estátua de manifestante do Black Lives Matter é retirada de Bristol 24h depois \\
\hline $24 / 07 / 2020$ & Sérgio Camargo diz que movimento Black Lives Matter piorou o racismo \\
\hline $11 / 08 / 2020$ & Dia do advogado: conheça Zaira Castro, jurista antirracista que luta pelos direitos das mulheres \\
\hline $16 / 08 / 2020$ & Ruby Bridges escreve livro infantil inspirado nos protestos Black Lives Matter \\
\hline 26/08/2020 & Sinto que não é nossa responsabilidade educar os brancos, diz Leigh-Anne em nova série da MTV \\
\hline 26/08/2020 & "A polícia precisa ser retratada de forma mais realista na TV", diz Andre Braugher, de Brooklyn 99 \\
\hline
\end{tabular}

Fonte: dados da pesquisa elaborados pelo autor do artigo.

Além desses resultados, foi retornado mais um (1) resultado de 2015. Aparentemente, o site Mundo Negro só exibe 10 resultados por consulta, sem páginas adicionais. No corpo de algumas das matérias, é possível encontrar um hiperlink para outras postagens relacionadas, o que caracteriza o processo de leitura nesse portal como hipertextual.

Já a pesquisa pela expressăo "Black lives matter" no portal Geledés retornou muitos resultados, agrupados por 11 páginas. Desses, elencamos os seguintes de 2020:

\section{Tabela 2 - Resultados para "Black lives matter" no Portal Geledés}

\begin{tabular}{|c|c|}
\hline Data & Título \\
\hline $15 / 07 / 2020$ & $\begin{array}{l}\text { Estátua de manifestante do movimento 'Black Lives Matter' substitui monumento de traficante de } \\
\text { escravos em Bristol, Inglaterra }\end{array}$ \\
\hline 10/07/2020 & Nova York estampa slogan ‘Black Lives Matter’ em frente à Trump Tower \\
\hline 03/07/2020 & $\begin{array}{c}\text { Menina de } 10 \text { anos faz sucesso com música sobre Black Lives Matter: 'Orgulhosa e } \\
\text { completamente triste', diz mãe }\end{array}$ \\
\hline $17 / 06 / 2020$ & Vidas negras importam: Miss Universo apoia movimento Black Lives Matter e luta antirracista \\
\hline 14/06/2020 & "As pessoas querem ser escutadas", diz Cherizar Crippen, líder do Black Lives Matter \\
\hline 08/06/2020 & 'Black Lives Matter': As três mulheres negras por trás do movimento contra o racismo \\
\hline 07/06/2020 & Como falar com sua família branca sobre racismo - Black Lives Matter \\
\hline 30/07/2020 & "É uma forma política de se manifestar", diz historiador sobre derrubada de estátuas \\
\hline $27 / 07 / 2020$ & Protestos contra racismo deixam morto e dezenas de presos nos EUA \\
\hline $17 / 07 / 2020$ & Julho das Pretas \\
\hline $13 / 07 / 2020$ & Joice Berth: 'Mobilização de comunidades é resultado do abandono político' \\
\hline 10/07/2020 & Vidas negras importam: Ringo se engaja na luta contra o racismo \\
\hline 07/07/2020 & Naomi Campbell abre Semana de Moda em Paris com discurso sobre racismo \\
\hline 07/07/2020 & Príncipe Harry diz que Commonwealth deve enfrentar seu passado colonial \\
\hline 06/07/2020 & Karol Conka reflete os "Tempos Insanos" em novo clipe \\
\hline 03/07/2020 & Antirracismo no Brasil: uma tarefa inadiável às pessoas brancas \\
\hline 02/07/2020 & $76 \%$ veem racismo no Brasil, mas só $28 \%$ admitem preconceito contra negros \\
\hline 02/07/2020 & Enquanto houver racismo, não haverá democracia \\
\hline 01/07/2020 & Wall Street: o código racial de que ninguém fala \\
\hline 29/06/2020 & Museu remove busto do ex-presidente do COI por causa de "legado racista" \\
\hline 27/06/2020 & 'Esquerda e direita brasileira são inábeis em incorporar o debate sobre o racismo' \\
\hline
\end{tabular}




\begin{tabular}{|c|c|}
\hline Data & Título \\
\hline $27 / 06 / 2020$ & Da militância de Hamilton à negligência de Djokovic, as diferentes posturas dos ídolos do esporte \\
\hline 26/06/2020 & Sorriso amarelo e a luta antirracista OU os tamagotchis da branquitude \\
\hline 22/06/2020 & Lewis Hamilton participa de protesto antirracista em Londres \\
\hline $17 / 06 / 2020$ & ‘Eu Não Sou Negro’ abre a janela para discutir sobre o Racismo \\
\hline $17 / 06 / 2020$ & Arcebispo de Cantuária exorta os anglicanos a agir contra o racismo \\
\hline $17 / 06 / 2020$ & \#VogueChallenge. Este desafio é de todos e pede mais diversidade na indústria da moda \\
\hline $12 / 06 / 2020$ & O que significa afirmar que as vidas dos negros e das negras importam? \\
\hline $11 / 06 / 2020$ & Manifestantes "decapitam" estátua de Cristóvão Colombo nos Estados Unidos \\
\hline $11 / 06 / 2020$ & Apoio a movimento antirracismo cresce após morte de George Floyd, diz pesquisa \\
\hline $11 / 06 / 2020$ & Discurso da 'passividade' do negro brasileiro é artimanha de ideologia racista \\
\hline 09/06/2020 & Norte-americanos brancos se unem aos protestos contra o racismo \\
\hline 09/06/2020 & Doze dias que abalaram os Estados Unidos \\
\hline 09/06/2020 & Caso George Floyd: 'Os EUA são um experimento social falido', critica filósofo \\
\hline 07/06/2020 & Michael Jordan doará R\$ 497 milhões a organizações engajadas na causa antirracista \\
\hline 02/06/2020 & Conheça 7 intelectuais que nos ajudam a entender o racismo no Brasil \\
\hline 02/06/2020 & Viola Davis compartilha link de petição que pede justiça no caso do menino João Pedro \\
\hline 01/06/2020 & Protestos por justiça para George Floyd recebem apoio de policiais \\
\hline $31 / 05 / 2020$ & Caso George Floyd: Protestos antirracistas saem dos EUA e chegam a Berlim, Londres e Toronto \\
\hline $30 / 05 / 2020$ & $4^{\mathrm{a}}$ noite de protestos nos EUA por morte de George Floyd deixa mortos e centenas de detidos \\
\hline $15 / 08 / 2020$ & $\begin{array}{l}\text { 'Espero que no futuro as mulheres possam tomar posse do que é seu', diz a afrotransfeminista } \\
\text { Giovanna Heliodoro }\end{array}$ \\
\hline $15 / 08 / 2020$ & Para além da cor da pele: O racismo estrutural e a violência policial \\
\hline $15 / 08 / 2020$ & Grupo racista dá 48 horas para deputadas negras deixarem Portugal \\
\hline $11 / 08 / 2020$ & Diretor de 'Pantera Negra' fala de filme sobre ativista assassinado: 'Estamos na mesma luta' \\
\hline $11 / 08 / 2020$ & 13 microagressões sofridas diariamente por quem é negro \\
\hline $31 / 07 / 2020$ & Único negro dos 81 conselheiros federais propõe cotas raciais para a OAB \\
\hline 29/07/2020 & Companhia das Letras tenta combater racismo nomeando editor de diversidade \\
\hline $24 / 06 / 2020$ & \#VIDASNEGRASIMPORTAM: e a branquitude depois da hashtag? \\
\hline $19 / 06 / 2020$ & Para você, antirracista \\
\hline $18 / 06 / 2020$ & As diversas formas da violência racista \\
\hline $18 / 06 / 2020$ & As estátuas do nosso desconforto \\
\hline $14 / 06 / 2020$ & Crossfit perde patrocinador e enfrenta crise após tuíte considerado racista \\
\hline $13 / 06 / 2020$ & Band-Aid terá curativos para diferentes tons de pele \\
\hline 06/06/2020 & Pilotos reagem à crítica de Hamilton e protestam contra racismo \\
\hline 05/06/2020 & Como colaborar com o ‘Vidas Negras Importam' sem silenciar o movimento \\
\hline
\end{tabular}

Fonte: dados da pesquisa elaborados pelo autor do artigo.

Além dessas matérias, encontramos outras de anos anteriores na busca pela expressáo "Black lives matter": uma (1) de 2010, uma (1) de 2012, catorze (14) de 2015, sessenta e nove (69) de 2016, trinta (30) de 2017, dezessete (17) de 2018, dezesseis (16) de 2019, além de outras quatro (4) de 2020, anteriores às manifestaçôes iniciadas em 26 de maio. Isso nos mostra que, assim como o corpo, a linguagem é atravessada de história.

Black Lives Matter năo é uma simples expressăo linguística que nomeia um protesto ocorrido em 2020. É a denominaçâo de um movimento criado nos EUA em 2014 para denunciar a violência policial contra a populaçâo negra. Observa-se uma maior emergência de enunciados como acontecimentos singulares (FOUCAULT, 2008) 
acerca desse movimento em 2016, mesmo ano de eleiçấo de Donald Trump para presidente dos EUA, com um forte discurso de ódio a negros, homossexuais e imigrantes.

Após a pesquisa de enunciados nesses dois portais, orientando-nos pelas regularidades discursivas (FOUCAULT, 2008), selecionamos dois enunciados de cada site, que tratam sobre os seguintes temas: a morte de George Floyd, os protestos contra o racismo desencadeados por esse assassinato policial e a derrubada de estatuas de escravistas para a edificaçăo de estátuas de manifestantes negros.

Do site Mundo Negro, selecionamos as matérias intituladas "BlackOutTuesday: Artistas aderem a campanha em apoio ao movimento negro", publicada em 02 de junho de 2020, e "Estátua de manifestante do Black Lives Matter é retirada de Bristol 24h depois", publicada em 16 de julho de 2020. Do Portal Geledés escolhemos as matérias “Estátua de manifestante do movimento 'Black Lives Matter' substitui monumento de traficante de escravos em Bristol, Inglaterra", publicada em 15 de julho de 2020, e " 4 a noite de protestos nos EUA por morte de George Floyd deixa mortos e centenas de detidos", publicada em 30 de maio de 2020.

A análise dos enunciados segue a proposta de análise enunciativa de Foucault (2008), que leva em consideraçâo os princípios de regularidade, dispersâo, raridade e descontinuidade, ratificada por Milanez (2019), que considera a descriçáo da materialidade do enunciado o primeiro passo para sua análise. Ela permite situar o que foi esse acontecimento histórico e sua discursivizaçăo pela mídia, que passa por um processo de documentaçăo em fotografias e palavras e conduz à definiçăo do objeto de que se fala, como faremos adiante, com base no arsenal teórico supracitado.

\section{EMERGÊNCIAS DO CORPO NEGRO E REINVENÇÃO DA MEMÓRIA COLONIAL: DISCURSOS, SABERES E PRÁTICAS DE RESISTÊNCIA}

Após a montagem do corpus, reagrupamos os enunciados perseguindo a formaçôes dos objetos (FOUCAULT, 2008). Assim, começamos as análises pelas duas matérias que tratam da morte de George Floyd e dos protestos que a seguiram. A matéria do Portal Geledés, do dia 30 de maio de 2020, foi a primeira desse site a tratar dos protestos, noticiando a realizaçâo de atos contra a morte de Floyd em mais de 30 cidades americanas, após o policial ter sido detido e acusado de homicídio, mas, após isso, conseguiu a liberdade. Sobre a morte e sua investigaçâo, a matéria apresenta o seguinte:

George Floyd morreu no dia 25 de maio, depois de ser asfixiado por 8 minutos e 46 segundos pelo policial branco Derek Chauvin em Minneapolis, no estado de Minnesota. Na sexta-feira (29), Chauvin foi detido e acusado de homicídio. Documentos obtidos pela rede americana CNN mostram que a fiança do policial foi estabelecida em US\$ 500 mil (cerca de R\$ 2,7 milhóes).

Segundo a acusaçăo contra Chauvin, ele manteve seu joelho sobre o pescoço de Floyd durante os 8 minutos e 46 segundos, sendo que nos últimos 2 minutos e 53 segundos o homem, negro, já estava inconsciente. A autópsia informou, entretanto, que năo houve "nenhum achado físico que apoie o diagnóstico de asfixia traumática ou estrangulamento". 
No entanto, o efeito conjunto de George Floyd ter sido asfixiado mais suas condiçōes de saúde pré-existentes e a possibilidade de haver substâncias intoxicantes em seu corpo "provavelmente contribuíram para sua morte", de acordo com a acusaçáo (GELEDÉS, 2020a, online).

Nesse enunciado, ocorre a formaçăo dos conceitos (FOUCAULT, 2008) de branquitude, associada ao policial, homicídio, para caracterizar o ato que ele cometeu, e negritude, para enunciar sobre George Floyd. A noçăo de branquitude é compreendida aqui como um conjunto de formas de privilégios dos brancos, que inclui o poder de definir o negro como perigoso. Tais conceitos emergem em um embate discursivo entre os saberes científicos que apontam que a morte de Floyd năo foi causada diretamente pela açâo do policial e os saberes das pessoas (FOUCAULT, 2013b) que assistiram esse acontecimento histórico e o transformaram em discurso.

Apesar de todo o aparato midiático em torno desse caso, a morte de Floyd năo foi atribuída ao policial pelos saberes científicos que penetraram seu corpo negro e morto em autópsias para enquadrá-la nas categorias médico-jurídicas da asfixia traumática e do estrangulamento. Em vez de levar em conta a imagem de Floyd sendo assassinado e gritando que náo conseguia respirar, a causa de sua morte foi atribuída à sua proveniência (FOUCAULT, 2013a), às condiçōes do seu próprio corpo, caracterizado como um corpo intoxicado por drogas, doente e que, portanto, merecia a morte.

Já em relaçâo aos protestos, a materialidade do enunciado situa esse acontecimento em cinco (5) fotografias das manifestaçōes ocorridas até aquela data. A primeira é de manifestantes brancos segurando faixas. Uma com a frase "end police violence" (fim da violência policial), escrita em caixa alta e na cor verde sobre um fundo branco, que suscitam modalidades enunciativas (FOUCAULT, 2008) para quem fala, como grito, esperança e paz, respectivamente. A outra é uma faixa preta com as seguintes informaçóes em branco: Oakland '09; Ferguson '14; Baltimore '15; Minneapolis '20, cores que também suscitam as discursividades da morte e da paz, respectivamente.

Esses nomes săo de lugares onde ocorreram mortes violentas de homens negros por policiais brancos, seguidos dos anos do ocorrido. As mortes săo explicadas em um "histórico" no fim da matéria. No caso de Baltimore, a morte de Freddie Gray, de 25 anos, sob custódia policial, foi qualificada como homicídio e acabou sendo arquivada. Em tal caso, năo havia as condiçōes tecnológicas e sociais que deram grande visibilidade à morte de George Floyd, inviabilizando o confronto entre um saber oficial e os saberes dominados (FOUCAULT, 2013b) que documentaram o acontecimento de sua morte.

Há uma terceira fotografia de uma mâo negra segurando um cartaz com a frase "Black lives matter" com a primeira e a última palavra em vermelho e a do meio em preto, em um fundo branco, suscitando posiçôes como a morte, o luto e a paz; uma fotografia de um homem caminhando em frente a um muro pichado com a frase, em vermelho, "kill one back" (mate um de volta) que materializa o assassinato, além da foto de um carro pegando fogo e um manifestante jogando extintor de incêndio em um prédio em chamas.

Nesses protestos, morreram um jovem de 19 anos, que "foi atingido depois que uma pessoa passou atirando de dentro de um carro contra uma multidăo que protestava no centro de Detroit, no Michigan" (GELEDÉS, 2020a, online), e um agente 
federal, baleado durante as manifestaçôes em Oakland. Trata-se de uma história de corpos alvejados por armas de fogo enquanto empreendem resistências e disciplinamentos. Além dessas mortes, houve pessoas atingidas por tiros, mas que sobreviveram, outras foram presas, houve vandalismo, roubos, incêndios e ataques à polícia, conforme dados da CNN americana, que embasa essa matéria, a qual foi replicada do portal G1, da Rede Globo.

Tal acontecimento é construído de embates năo só de corpos, mas também de discursos. Enquanto Ted Wheeler, prefeito de Portland, no Oregon, condenou os protestos pela ocorrência do que considera vandalismo, dizendo que "Isso náo é pedir mudança significativa nas nossas comunidades, isso é nojento" (GELEDÉS, 2020a, online), uma manifestante, identificada como Chelsea Peterson, disse que foi ao protesto porque "era importante para mim como uma pessoa branca participar porque é nossa responsabilidade desmantelar os sistemas de opressâo que criamos" (idem).

As falas aqui apresentadas apontam para diferentes posicionamentos dos sujeitos (FOUCAULT, 2008) sobre esse acontecimento histórico. Sâo diversos modos de enunciar as manifestaçóes contra o racismo e a violência policial. Por um lado, aqueles que os consideram violentos e caóticos, como o faz o prefeito de Portland, local em que, assim como em Ohio, houve declaraçăo de estado de emergência, com toque de recolher, além da ativaçăo da Guarda Nacional em Minneapolis, pela primeira vez após a Segunda Guerra Mundial. Por outro lado, pessoas brancas apoiaram as manifestaçōes e foram com seus corpos protestar contra esse sistema de poder.

Assim, a primeira reportagem de Geledés apresenta o acionamento da força policial para gerenciar as formas de resistência e sancionar as açôes dos corpos dos sujeitos que protestam contra as violências e racismos da própria estrutura do Estado. Já na matéria do Mundo Negro, publicada em 02 de junho de 2020, de autoria de Thais Prado, redatora do site, trata-se da participaçấo de pessoas famosas em eventos ligados ao Black lives matter, as quais registraram essa história, neste momento presente, utilizando a música para sinalizar apoio aos protestos. Um dos trechos é o que segue:

Movimento organizado por Jamila Thomas e Brianna Agyemang, duas mulheres pretas da música acontecerá para protestar e para apoiar os protestos antirracistas que tomaram conta de diversas cidades dos Estados Unidos após a morte de George Floyd, homem negro morto por um policial branco (PRADO, 2020b, online).

A matéria acime é escrita sem maiores atençōes à norma padrăo da língua portuguesa. Escrita em pretuguês (GONZALES, 1984), aponta para a ligaçâo do sujeito que enuncia (FOUCAULT, 2008) com o grupo afrodescendente, ou seja, situa sua proveniência (FOUCAULT, 2013a) e justifica o modo de enunciar o racismo.

$O$ enunciado se materializa com a frase \#BlackOutTuesday, escrito com letras brancas em um fundo preto, suscitando as posiçôes de luto e paz para o sujeito que enuncia (FOUCAULT, 2008). A morte de George Floyd ocorreu em 25 de maio de 2020 e os protestos que a seguiram começaram no dia 26 de maio, em Minneapolis, Minnesota, nos Estados Unidos. Esse evento foi importante porque ocorreu em meio à pandemia do corona vírus e fez com que as pessoas saíssem do isolamento social, causando aglomeraçôes, resistindo às recomendaçôes sanitárias da Organizaçăo Mundial da Saúde (OMS) e expondo seus corpos ao risco de adoecimento e morte. 
Por outro lado, esse acontecimento ganhou maior visibilidade nas mídias em virtude desse mesmo isolamento social, pois as pessoas estavam mais tempo dentro de casa e utilizando as mídias sociais como forma de sociabilidade. Esse acontecimento passou a ser mais discursivizado e, ao mesmo tempo, mais visto, ou seja, ocorreu uma maior produçâo e circulaçăo desse acontecimento como discurso.

O uso da hashtag $\left(^{\#}\right)$ na matéria simboliza a manifestaçăo virtual. As artistas săo enunciadas como formadoras de opiniâo, ou seja, pessoas que utilizam de seu poder de mobilizaçăo social para formular e pôr em circulaçâo saberes dominados (FOUCAULT, 2013b), que irăo enfrentar diversas formas de saberes hierarquizantes, que disciplinam e supliciam o corpo negro. A autora da matéria também se posiciona como sujeito que governa (FOUCAULT, 2009), instruindo o leitor a utilizar a hashtag em apoio ao movimento, instando-o a fazer um uso correto desse recurso, sem utilizar mais de uma na mesma postagem, de modo a auxiliar quem faz procura por esses temas na internet.

No Brasil, em virtude do isolamento social, a internet foi a principal forma de manifestaçăo das pessoas em relaçăo aos acontecimentos de assassinatos de pessoas negras pela polícia. Em seguida à morte de Floyd, nos EUA, Joăo Pedro foi assassinado dentro de casa, no Rio de Janeiro, e uma criança negra morreu em Recife, levando as pessoas a protestarem nas redes sociais de forma simbólica, colocando um fundo preto, em sinal de luto, e elaborando "textóes" sobre as operaçóes policiais nas favelas cariocas. Em todo caso, trata-se de embates de corpos, ainda que virtualmente.

Passemos aos dois enunciados que tratam do corpo esculpido de Jen Reid, colocando em questâo as lutas pela memória e a participaçâo do negro na formaçấo social, questâo que emerge após a morte de Floyd. No Geledés, foi publicada uma matéria em 15 de julho de 2020 sobre a edificaçăo da estátua da manifestante britânica Jen Reid, que substituiu a do escravocrata Edward Colston (1636-1721), edificada em 1895, em bronze e, depois, jogada no rio Avon, em junho, por manifestantes do Black lives matter.

A disputa pela memória situa um conjunto de atos de rememoraçâo/comemoraçâo (LE GOFF, 1990) em torno de processos civilizatórios do povo britânico e também em outras partes do mundo, pois essa luta tornou-se transversal (FOUCAULT, 2009). A memória é essencial à manutençăo da identidade de um povo ou naçăo, sendo alvo de disputas de poder de determinar o que deve ser lembrado ou esquecido. Ela ordena os fatos históricos em narrativas e cronologias de acontecimentos que serâo acionados por operaçōes de rememoraçăo, que é uma de suas formas de funcionamento, e comemoraçăo, que é compreendida como "a celebraçăo através de um momento comemorativo de um acontecimento memorável" (LE GOFF, 1990, p. 432). A comemoraçâo assume as formas de inscriçăo, construçăo de monumentos, arquivos, bibliotecas, museus, emissâo de documentos, etc.

O jornalista é um profissional da memória e as mídias revolucionaram a operaçâo de comemoraçăo/rememoraçâo. No enunciado em questăo, temos, de um lado, a história narrada sob a perspectiva dos escravocratas elevados à categoria de heróis e, de outro lado, a edificaçáo da estátua de uma mulher negra que luta por igualdade racial. 0 acontecimento da edificaçăo da escultura é narrado da seguinte forma no portal: "com os debates acerca da justiça racial e do racismo, o objeto vinha se tornando cada vez mais controverso e foi alvo durante as manifestaçóes que aconteceram depois da morte do segurança negro, George Floyd, nos Estados Unidos" (GELEDÉS, 2020b, online). 
Nesse excerto, ocorre a formaçăo dos conceitos (FOUCAULT, 2008) de justiça racial e de racismo. Apesar da historicidade dos debates em torno desses temas e de inúmeros pessoas se dizerem năo racistas ou antirracistas, eles emergem em virtude da persistência da intolerância contra os negros. Esse debate perpassa a exclusăo social, a marginalidade e a negaçâo de direitos essenciais, questôes postas em pauta na luta pela memória social e nas discussōes de pensadores como Gonzales (1984) há décadas.

A estátua da manifestante negra foi projetada pelo artista britânico Marc Quinn. O monumento é apresentado na materialidade do enunciado e descrito como "uma manifestante negra do movimento que surge com o punho erguido em uma saudaçâo ao Black Power" (GELEDÉS, 2020b, online), movimento de empoderamento dos negros. O gesto corporal da estátua é famoso por ter sido feito pelo grupo americano Panteras Negras, de luta contra o racismo, e foi reproduzido diversas vezes nas manifestaçôes.

Ele nos coloca diante de um corpo atravessado de história (FOUCAULT, 2013a), visto que remete a mais de 50 anos de lutas contra o racismo e se atualiza nos protestos contra a morte de George Floyd. $O$ gesto foi reproduzido por um homem negro em Sáo Paulo, enquanto era confrontado por um grupo de apoiadores do presidente Jair Bolsonaro, e feito também pela filósofa americana Ângela Davis, quando participou das manifestaçóes antirracistas. As fotografias de pessoas fazendo esse gesto foram divulgadas nas mais variadas mídias, saturando-se por essa incessante repetiçăo e se atualizada pelo acontecimento que envolve o enunciado (FOUCAULT, 2007).

Jen Reid foi fotografada reproduzindo tal gesto ao voltar de uma manifestaçăo em junho, quando o pedestal com a estátua de Colstol estava vazio. Essa fotografia serviu para a realizaçăo da escultura em tamanho real, utilizando resina preta. A obra representa para o artista, conforme uma fala sua reportada na matéria, "uma personificaçâo e amplificaçâo das idéias e experiências de Jen, e do passado, presente e sua esperança de um futuro melhor (sic.)" (GELEDÉS, 2020b, online).

A escultura, denominada "A Surge of Power (Jen Reid) 2020", foi retirada porque o artista nâo tinha autorizaçăo para deixá-la no local. Mesmo assim, sua elaboraçâo foi um acontecimento registrado, tornando-a um enunciado com ligaçâo com todos os pontos da história, como consta na fala de Marc Quinn supracitada, ou seja, é uma materializaçâo das lutas antirracista do passado, do presente e do futuro, delineando desde já sua inscriçâo em uma série enunciativa (FOUCAULT, 2008).

Esse acontecimento foi noticiado no site Mundo Negro, replicando uma matéria publicada originalmente pela revista Marie Clarie para o Globo.com, como segue:

A escultura de uma manifestante do movimento Black Lives Matter, que substituiu a estátua do comerciante de escravos Edward Colston em uma praça de Bristol, na Inglaterra, foi removida 24 horas depois de ter sido colocada no local. Uma portavoz do conselho da cidade confirmou que a imagem seria levada para um museu para que o artista Marc Quinn pudesse retirar ou doar para a coleçăo (PRADO, 2020c, online).

Mesmo năo tendo permissăo para lembrar as lutas do passado e as atuais contra o racismo, a escultura foi considerada uma obra de arte, podendo ficar restrita ao museu, lugar de memória por excelência, ou devolvida a seu autor. A permissăo năo foi dada 
porque a obra ficaria em um local onde ela iria sempre lembrar aos transeuntes que houve um período em que pessoas negras eram vendidas para realizar trabalhos forçados e que, na atualidade, ainda se têm remanências desse regime escravocrata, pois as pessoas que o perpetraram săo rememoradas como heróis, ao passo que a justiça social para os negros nunca foi efetivada em nenhum país, diferente do que ocorreu com muitos escravistas, que foram indenizados pelos governos de diversos países.

Esse ato atesta que há uma luta em torno da memória social inglesa sobre a escravidăo. A escultura representa um processo de rememoraçâo (LE GOFF, 1990) da participaçâo do negro na formaçăo do povo britânico, além de retificar os significados do processo de civilizaçấo da Europa, conforme outro excerto da mesma matéria:

Nas redes sociais, manifestantes dizem que o conselho deveria ter permitido que a estátua com a imagem da manifestante Jen Reid permanecesse no local por mais tempo, considerando que a escultura de Colston esteve no mesmo local por mais de um século (PRADO, 2020c, online).

Desse modo, as lutas contra a morte de George Floyd tornaram-se transversais e contra diversas formas de sujeiçăo (FOUCAULT, 2009). O corpo é a superfície de emergência desse acontecimento (FOUCAULT, 2013a), o local em que ele se inscreve. Foi a partir do acontecimento do corpo negro asfixiado de George Floyd e sua difusâo em imagem fixa, em movimento e áudios que emergiram diversos enunciados, os quais registram e interpretam a história do tempo presente na mídia alternativa e corporativa.

Tal acontecimento ressonou no corpo de Reid, edificado em resina preta e distribuído em praça pública aos olhares que o fitam com coragem e aos que dele desviam para náo lembrar do racismo. Essa irrupçăo de enunciados feita pelas mídias situa formas de emergência do acontecimento e de proveniências do corpo (FOUCAULT, 2013a) em uma história genealogicamente organizada, cuja origem se dissipou.

\section{CONCLUSÕES}

Neste artigo, analisamos quatro enunciados da mídia que discursivizam os acontecimentos da morte de George Floyd por asfixia e as manifestaçóes que se seguiram a ela, entre as quais houve a edificaçăo de uma escultura da manifestante Jen Reid. Esses enunciados nos situam na história arruinando o corpo (FOUCAULT, 2013a) negro.

Para realizar essa discussâo, apresentamos algumas consideraçōes teóricas acerca do acontecimento, do corpo e do saber dominado, de modo a questionar o lugar do corpo negro na história de países colonizados, além das situaçōes enfrentadas por sujeitos negros que fazem entrever o funcionamento de uma necropolítica (MBEMBE, 2016).

Encetamos algumas consideraçōes metodológicas para a realizaçăo da análise enunciativa a partir das materialidades discursivas veiculadas na mídia. Pelas análises dos enunciados, concluímos que, nas reportagens dos dois sites em que o objeto de discurso é a morte de Floyd, há a formaçâo alguns conceitos, como os de branquitude, negritude, justiça social, racismo, que vâo constituir temas, organizar as formas estratégicas de apresentaçấo do enunciado e delimitar os modos de os sujeitos se posicionarem sobre eles. 
A materialidade dos enunciados também suscita posiçôes sobre quem fala, como os sentidos de morte, luto, paz, que perpassam o cromático enunciativo dos dois sites, situando-os como superfície de emergência de denúncias contra a violência policial, em vez de buscar um lugar de suposta neutralidade, além de se posicionarem em defesa das lutas dos negros por uma memória social que lembre os seus feitos na história.

Além disso, as modalidades enunciativas (FOUCAULT, 2008) apresentadas nessas duas mídias alternativas sâo de pessoas negras, para um público negro, mas sâo enunciados elaborados a partir de formulaçōes da grande mídia, além de apresentar matérias já veiculadas nos grandes portais, atestando a colaboraçâo entre essas mídias. 


\section{REFERÊNCIAS}

ALMEIDA, A. W. B. de. A ideologia da decadência: leitura antropológica a uma história de agricultura do Maranhâo. 2. ed. Rio de Janeiro: Editora Casa 8/ Fundaçăo Universidade do Amazonas, 2008.

CAPELATO, M. H. História do tempo presente: a grande imprensa como fonte e objeto de estudo. In: DELGADO, L. de A. N.; FERREIRA, M. de M. (Org.) História do tempo presente. Rio de Janeiro: Editora FGV, 2014, p. 299-315.

COURTINE, J.J. Discursos sólidos, discursos líquidos: a mutaçăo das discursividades contemporâneas. Trad. Carlos Piovezani. In: SARGENTINI, V.; GREGOLIN, M. R. (orgs.). Análise do discurso: heranças, métodos e objetos. Sâo Carlos: Editora Claraluz, 2008, p. 11-19.

FOUCAULT, M. Aula de 17 de março de 1976. In: FOUCAULT, M. Em defesa da sociedade: Curso no Collège de France (1975/1976). Trad. Maria Ermantina Galvăo. 4. ed. Săo Paulo: Martins Fontes, 1999, p. 285-315.

A vida dos homens infames. In: . Ditos \& Escritos IV: Estratégia, Poder-Saber. Trad. Vera Lucia Avellar Ribeiro. 2. ed. Rio de Janeiro: Forense Universitária, 2003, p. 203-222.

A ordem do Discurso. Trad. Laura Fraga de Almeida Sampaio. 15. ed. Săo Paulo: Ediçôes Loyola, 2007.

A arqueologia do saber. Trad. Luiz Felipe Baeta Neves. 7. ed. Rio de Janeiro: Forense Universitária, 2008.

O sujeito e o poder. In: DREYFUS, H. L.; RABINOW, P. Michel Foucault: uma trajetória filosófica para além do estruturalismo e da hermenêutica. Rio de Janeiro: Forense Universitária, 2009, p. 231-249.

Nietzsche, a genealogia e a história. In: FOUCAULT, M. Microfísica do poder. Trad. Roberto Machado. 26. ed. Săo Paulo: Graal, 2013a, p 55-86.

. Genealogia e poder. In:FOUCAULT, M. Microfísica do poder. Trad. Roberto Machado. 26. ed. Sâo Paulo: Graal, 2013b, p 262-277.

GELEDÉS. $4^{\mathrm{a}}$ noite de protestos nos EUA por morte de George Floyd deixa mortos e centenas de detidos. Portal Geledés. Săo Paulo, violência racial e policial, 30 mai. 2020a, online. Disponível em: https://www.geledes.org.br/4a-noite-de-protestos-nos-eua-pormorte-de-george-floyd-deixa-mortos-e-centenas-de-detidos/. Acesso em: 29 ago. 2020.

GELEDÉS. Estátua de manifestante do movimento ‘Black Lives Matter' substitui monumento de traficante de escravos em Bristol, Inglaterra. Portal Geledés. Săo Paulo, Em pauta, Esquecer? Jamais, 15 jul. 2020b. Disponível em: https://www.geledes.org.br/ estatua-de-manifestante-do-movimento-black-lives-matter-substitui-monumento-detraficante-de-escravos-em-bristol-inglaterra/. Acesso em: 29 ago. 2020.

GONZALES, L. Racismo e sexismo na cultura brasileira. In: Revista Ciências Sociais Hoje. Fortaleza, p. 223-244, 1984. 
JENKINS, H. Cultura da convergência: a colisăo entre os velhos e novos meios de comunicaçăo. Traduçăo de Susana Alexandria. 2. ed. Sáo Paulo: Aleph, 2009.

LE GOFF, J. História e memória. Traduçăo: Bernardo Leităo. Campinas, SP: Editora da UNICAMP, 1990.

MBEMBE, Achille. Necropolítica. Arte \& Ensaios. Rio de Janeiro, n. 32, 2016, p. 123-151. Disponível em: https://revistas.ufrj.br/index.php/ae/article/view/8993. Acesso em: 09 ago. 2020.

MILANEZ, N. Audiovisualidades: elaborar com Foucault. Londrina, PR: Eduel; Guarapuava, PR: Ed. Unicentro, 2019.

PRADO, Thais. Estátua de manifestante negra é erguida no lugar da que representava o escravagista Edward Colston. Mundo Negro. Săo Paulo, 15 de julho de 2020a, online. Disponível em: https://mundonegro.inf.br/estatua-de-manifestante-negra-e-erguidano-lugar-da-que-representava-o-escravagista-edward-colston/. Acesso em: 29 ago. 2020.

. BlackOutTuesday: Artistas aderem a campanha em apoio ao movimento negro. Mundo Negro. Sāo Paulo, Comunidade negra, Noticiário, 02 jun. 2020b, online. Disponível em: https://mundonegro.inf.br/blackouttuesday-artistas-aderem-a-campanha-em-apoio-ao-movimento-negro/. Acesso em: 29 ago. 2020.

. Estátua de manifestante do Black Lives Matter é retirada de Bristol 24h depois. Mundo Negro. Sâo Paulo, Comunidade negra, Noticiário, 16 jul. 2020c, online. Disponível em: https://mundonegro.inf.br/estatua-de-manifestante-do-black-lives-matter-e-retirada-de-bristol-24h-depois/. Acesso em: 29 ago. 2020.

SCHWARCZ, L. M. 0 espetáculo das raças: cientistas, instituiçôes e questăo racial no Brasil (1870-1930). Sấo Paulo: companhia das Letras, 1993.

TAKAHASHI, Henrique Yagui. Sorriso amarelo e a luta antirracista OU os tamagotchis da branquitude. Portal Geledés. Sáo Paulo, Guest Post, Questăo Racial, 6 jun. 2020, online. Disponível em: https://www.geledes.org.br/sorriso-amarelo-e-a-luta-antirracista-ou-os-tamagotchis-da-branquitude/. Acesso em: 29 ago. 2020.

WEFFORT, F. Jornais săo partidos? In: Lua Nova, Săo Paulo, v. 1, n . 2, 1984. Disponível em: http://www.scielo.br/scielo.php?script=sci_arttext\&pid=S0102-64451984000200008. Acesso em: 25 fev. 2019. 